\title{
Linear lichen nitidus: An unusual clinical presentation!
}

\author{
Mariem Mohamed ${ }^{1}$, Yosra Soua ${ }^{1}$, Adnène Moussa $^{2}$, Jameleddine Zili ${ }^{1}$ \\ ${ }^{1}$ Departement of Dermatology, Monastir University Hospital, College of Medicine of Monastir, Monastir, Tunisia, \\ ${ }^{2}$ Department of Pathology, Fattouma Bourguiba University Hospital, Monastir, Tunisia
}

Corresponding author: Dr. Mariem Mohamed, E-mail: mariemmohamed79@yahoo.fr

Lichen nitidus (LN) is a rare chronic inflammatory disease of unknown etiology. It predominantly affects children and young adults. Its clinical manifestation typically corresponds to erythematous or flesh-colored, asymptomatic or little pruritic mini papules, often located in the trunk, genitalia, and extremities. The linear arrangement of this dermatosis seems rare. To our knowledge, only 2 cases of linear lichen nitidus have been reported in the literature $[1,2]$. Our case hence corresponds to the third linear LN case.

This was a 23-year-old girl with no notable medical history, who consulted for papular discreetly pruritic lesions of the right hand extending to the forearm. The cutaneous examination revealed multiple erythematous millimeters, brilliant mini papules, taking a linear arrangement (Fig. 1). The rest of the integument, the mucous membranes, and the skin appendages were

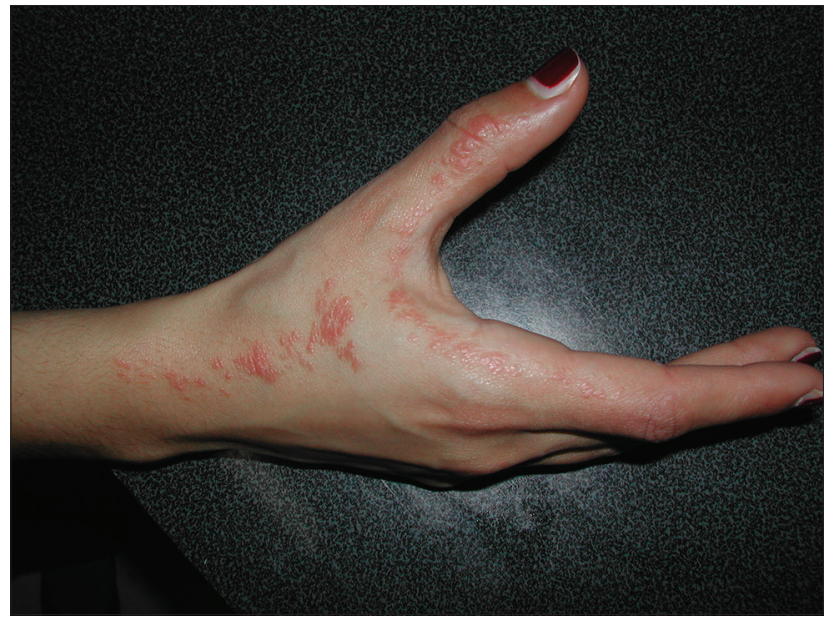

Figure 1: Erythematous millimeters, brilliant mini papules, taking a linear arrangement in the right hand. unharmed. The histological examination of a biopsy specimen showed a focally acanthotic epidermis with ortho-hyperkeratosis and a dense inflammatory infiltrate occupying the widened dermal papillae (Fig. 2). The papillary infiltrate was granulomatous comprising lymphocytes, histiocytes and giant cells with the presence of some apoptotic bodies (Fig. 3). In our case, the diagnosis strongly suspected of typical skin lesions was confirmed by the histological study.

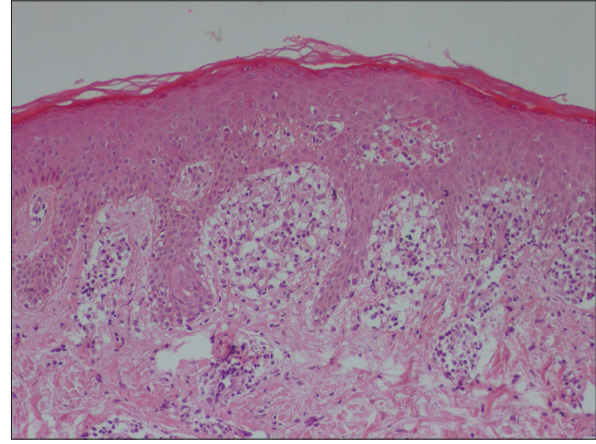

Figure 2: Lichenoid infiltrates of widened dermal papillae (H\&E x100)

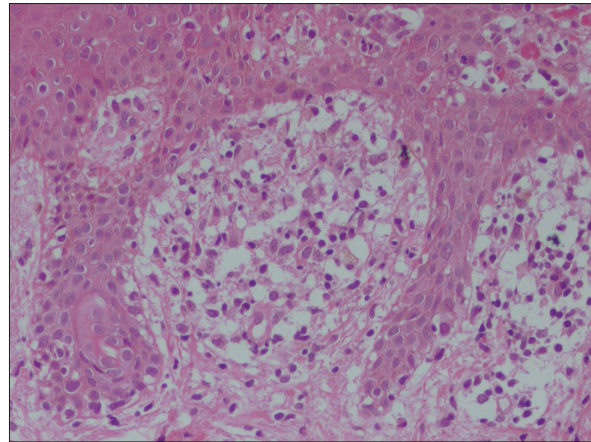

Figure 3: Granulomatous infiltrate comprising lymphocytes, histiocytes and giant cells with the presence of some apoptotic bodies on top right (H\&E x200).

\footnotetext{
How to cite this article: Mohamed M, Soua Y, Moussa A, Zili J. Linear lichen nitidus: An unusual clinical presentation! Our Dermatol Online. 2017;8(2):218-219. Submission: 01.09.2016; Acceptance: 09.11.2016 DOI: $10.7241 /$ ourd.20172.60
} 
www.odermatol.com

\section{REFERENCES}

1. Prigent F, Cavelier-Balloy B, Lemarchand-Venencie F, Civatte J. Linear lichen nitidus. Ann Dermatol Venereol. 1989;116:814-5.

2. Petrozzi JW, Shmunes E. Linear lichen nitidus. Cutis. 1970;6:1109-12.

Copyright by Mariem Mohamed, et al. This is an open-access article distributed under the terms of the Creative Commons Attribution License, which permits unrestricted use, distribution, and reproduction in any medium, provided the original author and source are credited.

Source of Support: Nil, Conflict of Interest: None declared. 